\title{
TRANSPLANTING THE UNITED STATES' STYLE OF SAFE HARBOUR PROVISIONS ON INTERNET SERVICE PROVIDERS VIA MULTILATERAL AGREEMENTS: CAN ONE SIZE FIT ALL?*
}

\author{
Suzi Fadhilah Bt. Ismail ${ }^{* *}$ \\ Ida Madieha Abdul Ghani Azmi*** \\ Mahyuddin Daud****
}

\begin{abstract}
Ideally, internet service providers (ISP) should not be burdened with policing contents that pass through their services as they have no editorial control over them. The United States Digital Millennium Copyright Act 1998 (DMCA) changes the ball game by making it mandatory on ISPs to take down infringing copyright materials if they received a notice and takedown request from a copyright holder. In exchange, the ISPs enjoy safe harbour from any liabilities that might arise from their user's action. Serious efforts are needed to transpose a similar system via negotiations and multilateral treaties and agreements involving a number of countries such as through the Trans-Pacific Partnership (TPP) Agreement. Despite the withdrawal of the United States' (US) from the TPP, and in view of the global initiatives of harmonization of intellectual property (IP) laws, this article aims to explore the different system of ISPs' obligations and liabilities in the twelve TPP member countries. It also examines some of the strengths and weaknesses of each system. It concludes with an
\end{abstract}

* This paper was presented in "2016 International Academic Conference on Social Sciences (IACSS)" in Tokyo, on December 6-8, 2016, with no correction.

** Assistant Professor at the Department of Civil Law, Ahmad Ibrahim Kuliyyah of Laws, International Islamic University of Malaysia. Email: suzi@iium.edu.my.

${ }^{* * *}$ Professor at the Department of Civil Law, Ahmad Ibrahim Kuliyyah of Laws, International Islamic University of Malaysia. Email: imadieha@iium.edu.my. **** Assistant Professor at the Department of Civil Law, Ahmad Ibrahim Kuliyyah of Laws, International Islamic University of Malaysia. Email: mahyuddin@iium.edu.my. 
argument that whilst some form of safe harbour should be created to assist IP right owners in policing their right, the US private notice and takedown system is not without its flaws and hence, other existing systems which are adopted in some of the TPP member countries are equally feasible and serve a common purpose in tackling the issue of copyright infringement vis-à-vis ISP liability. Eventually, there is no compelling reason to impose one single system on all the TPP member countries to police the internet via ISP liability.

Keywords: internet service provider, notice and takedown procedure, court mediated takedown, safe harbour, Trans-Pacific Partnership Agreement, infringement, liabilities, intellectual property right

\title{
PENERAPAN SISTEM "SAFE HARBOUR" DARI AMERIKA SYARIKAT KEATAS PEMBERI PERKHIDMATAN ATAS SESAWANG MELALUI PERJANJIAN MULTILATERAL: BOLEHKAH SATU SISTEM MENEPATI KEPERLUAN SEMUA NEGARA?
}

\begin{abstract}
ABSTRAK
Para pembekal perkhidmatan internet tidak sepatutnya dibebankan dengan tanggung jawab tambahan untuk mengawasi segala isi kandungan maklumat dan data yang menggunakan perkhidmatan mereka kerana mereka tidak mempunyai hak kawalan ke atas isi kandungan maklumat dan data tersebut. Akta Hakcipta Digital Millennium 1998 (Amerika Syarikat) telah mengubah keadaan ini dengan meletakkan kewajipan ke atas pembekal perkhidmatan internet untuk bertindak dengan menarik balik kandungan yang menyalahi hak cipta jika mereka menerima notis dan permohonan dari pemilik hak cipta untuk menarik balik kandungan yang berkenaan. Sebagai balasannya, pembekal perkhidmatan internet diberi perlindungan yang dinamakan 'safe harbour' untuk melindungi mereka dari liabiliti dan tindakan yang mungkin diambil oleh pengguna interent. Usaha-usaha yang serius untuk menerapkan sistem dan prosedur yang serupa boleh dilihat melalui perjanjian multilateral melibatkan beberapa buah negara, contohnya Perjanjian Perkongsian Trans Pasifik (TPP). Walaupun US telah membuat keputusan untuk menarik diri daripada TPP, berdasarkan usaha-usaha untuk mengharmonikan undangundang, artikel ini bertujuan untuk menyelidik dan menganalisa beberapa perbandingan yang penting di antara liabiliti pembekal perkhidmatan
\end{abstract}


internet antara dua belas negara anggota TPP. Makalah ini membahaskan, walaupun 'safe harbour' sepatutnya diwujudkan untuk membantu dan memudahkan pemilik hak cipta dalam mengawasi hak-hak mereka, sistem yang diamalkan oleh US, iaitu melalui pemberitahuan persendirian untuk menarik balik kandungan juga mempunyai kelemahannya, sedangkan dengan sistem-sistem lain yang diamalkan oleh negara-negara anggota TPP termasuk sistem dua kali notis dan juga sistem penglibatan mahkamah untuk menarik balik kandungan yang menyalahi hakcipta juga berfungsi dengan baik dalam menangani isu pelanggaran hakcipta. Kesimpulannya, tidak ada sebab yang kukuh untuk menerapkan satu sistem ke atas kesemua negara-negara ahli TPP.

Kata kunci: pemberi khidmat atas sesawang, pemberian notis dan internet service provider, pemberian notis dan prosedur penurunan, prosedur penurunan melalui mahkamah, "safe harbour", Perjanjian Perkongsian Rentas Pasifik, Perjanjian Perkongsian Trans-Pasifik, perlanggaran, liabiliti, hak cipta dan harta intelek

\section{INTRODUCTION}

It is a well-established fact that Internet Service Providers (hereinafter referred to as 'ISPs') ${ }^{1}$ and their services play a significant role and contribute greatly to the rapid growth and advancement of the Internet. Nevertheless, ISPs are not free from the risk of being imposed with legal liabilities, both primary and secondary, on the basis that they provide and facilitate services from hosting to caching, routing and so forth. In this regard, it is no surprise that such liabilities are attributed to ISPs as they are seen as the best entity to take any possible action against infringing sites simply because they are regarded as the gatekeeper of the Internet. In order to encourage the ISP's to act against the infringer, there is a specific legal mechanism that has been introduced, which is known as

\footnotetext{
${ }^{1}$ Article 18.81:(a) \& 18.82:2(a) of TPP Agreement defines ISP as: "a provider of online services for the transmission, routing, or providing of connections for digital online communications, between or among points specified by a user, of material of the user's choosing, undertaking the functions of transmitting, routing or providing connections for material without modification of its content or the intermediate and transient storage of that material done automatically in the course of such a technical process."
} 
'safe harbour'. ${ }^{2}$ This method gives a mandate and some protection to ISPs to enable them to take action against the infringer, provided that relevant notifications are submitted to the ISPs by the affected IP owner.

In the US, this system is specifically known as the notice and takedown procedure. The procedure apparently originated from the US via its legislation i.e. the United States Digital Millennium Copyright Act 1998 (hereinafter 'DMCA'). ${ }^{3}$ Since then, legal provisions pertaining to safe harbour have been widely applied in the implementation of the notice and takedown procedure and they serve as a powerful and effective mechanism in the policing of online copyright infringement. ${ }^{4}$

Nevertheless, it is to be noted that different countries across the globe have different standards in relation to ISP's liabilities. Another important fact is that, for the purpose of keeping pace with the very rapid growth of the internet, the conservative passive reactive approach is considered outdated and ineffective in tackling the challenging issue of policing the massive numbers of downloading and online file sharing activities. For example, in the year 2003 alone, it was found that there were more than three million simultaneous users sharing over a half a billion files on the most popular network (FastTrack/KaZaA). ${ }^{5}$ Consequently, the affected parties, notably the IP owners are now resorting to demand for more onerous tasks and obligations on the ISPs so that the latter would take a proactive and preventive approach in safeguarding the IP owners' rights

217 U.S.C. § 512(c), DMCA.

${ }^{3}$ DMCA was signed into law by President Clinton on October 28, 1998. It addresses a number of significant copyright-related issues, which includes the "Online Copyright Infringement Liability Limitation Act," under Title II, that creates limitations on the liability of online service providers for copyright infringement when engaging in certain types of activities. Accessed on 3 October 2018, https://www.copyright.gov/legislation/dmca.pdf.

${ }^{4}$ Vojtech Mlynar, "A Storm in ISP Safe Harbor Provisions: The Shift From Requiring Passive-Reactive to Active-Preventive Behaviour and Back", Intellectual Property Law Bulletin 19 (2014):1-28.

${ }^{5}$ Felix Oberholzer-Gee and Koleman Strumpf, "The Effect of File Sharing on Record Sales An Empirical Analysis", (2004), accessed September 29, 2018, http://www.unc.edu/ cigar/papers/FileSharing_March2004.pdf . 
and interest. ${ }^{6}$

Although the US has decided to withdraw from the Trans-Pacific Partnership Agreement ("TPP"), ${ }^{7}$ it is observed that some of the provisions of TPP Agreement ${ }^{8}$ remain relevant to facilitate the global effort towards harmonization of laws. Those provisions could serve as a useful guide and reference in relation to some initiatives to impose similar obligations via bilateral agreement or regional multilateral agreements, such as the Comprehensive and Progressive Agreement for the Trans-Pacific Partnership (hereinafter "CPTPP"). ${ }^{9}$ As the main focus of the TPP Agreement is to reach a global standard on enforcement of obligations, it is no wonder that ISP's liabilities ${ }^{10}$ are among the binding commitments under the Agreement. Reaching the TPP standards would require a legislative amendment among the twelve TPP member countries (namely the US, New Zealand, Australia and Malaysia, Japan, Canada, Chile, Singapore, Brunei, Mexico, Peru and Vietnam). The process may be easy to those countries which have already put in place some forms of notice and takedown procedures. Even then, there are various versions and approaches to the safe harbour method as there is no global standard on how to apply it. Meanwhile, for countries with no mechanism in place, reaching TPP standards would require massive revision.

\footnotetext{
${ }^{6}$ Supra, note 2.
}

7 The Trans-Pacific Partnership (TPP) is a trade agreement between 12 countries; Australia, Brunei, Canada, Chile, Japan, Malaysia, Mexico, New Zealand, Peru, Singapore, Vietnam, and United States. After series of negotiation, it was signed on 4 February 2016, but could not enter into force as the U.S. withdrew from the pact on 23 January 2017. https://www.cfr.org/backgrounder/what-trans-pacific-partnership-tpp .

8 The TPP full text is available at this link: https://ustr.gov/tradeagreements/free-trade-agreements/trans-pacific-partnership/tpp-full-text, accessed October 6, 2018.

${ }^{9}$ Eleven TPP countries have decided to proceed with CPTPP, even without US participation, in reviewing the existing clauses and rebranding the regional agreement, $\quad$ accessed September 29, 2018, http://fta.miti.gov.my/index.php/pages/view/71?mid=40 .

10 Section $\mathbf{J}$ of Article 18, Chapter 18 Intellectual Property https://ustr.gov/sites/default/files/TPP-Final-Text-Intellectual-Property.pdf . 
From a survey of all the twelve-member countries, they can be divided into four main groups. The first group, led by the United States, is practising a system of the US style private takedown notices (applying safe harbour). The countries which subscribe to this group are New Zealand, Australia and Malaysia. The second approach as implemented by Japan and Canada which is known as the notice and notice system whereby websites that receive notification are given seven days to respond. The third approach as adopted by Chile and Singapore is the court mediated system. The system is unique in the sense that it requires court's involvement and hence, takedown can only be carried out upon the court's order. The fourth group involve countries with no effective take down system. Belonging to this category are Brunei, Mexico, Peru and Vietnam.

This article uses a qualitative research method, namely a content analysis of the existing literature from journals, articles, periodicals and various websites. A doctrinal analysis is applied to examine the relevant laws pertaining to ISP liability in TPP member countries. The article starts with a scrutiny of the relevant law and practices on the notice and takedown procedure in the twelve TPP member countries. The discussion is organized according to the approaches adopted by the countries starting with the private notice, followed by notice and notice and court mediated takedown notices. For the sake of completion, the countries with no effective takedown procedure are also briefly covered. In scrutinizing the relevant laws and legislations on ISP liability and safe harbour provisions, the article seeks to address the issue of whether the various approaches which vary from one country to another, are feasible to address the issue of ISP liability and copyright infringement. From here an analysis of the strengths and weaknesses of each system is made. Finally, this work is concluded with the answer to the main question; i.e whether one single system of safe harbour protection for ISP should be imposed on all TPP member countries, since many of them already have their own system in place.

\section{THE PRIVATE NOTICE TAKEDOWN PROCEDURE}

This part deals with the approaches and procedures adopted in the first type of the safe harbour method. Since it is led by the United States, the discussion begins with an extrapolation of the position there first before proceeding to other jurisdictions. 


\section{United States}

The DMCA was passed in 1998 to promote the growth of the internet. ${ }^{11}$ It was legislated with the main objective of balancing the interests of the copyright owners and users, and to tackle the issue of copyright infringement, which was associated with the rapid growth of the internet usage. The Act has introduced a safe harbour for ISPs that fulfil all the requirements as provided under the Act with the ultimate aim to protect the ISPs from losses or harm that might be imposed on them in consequence of their action. 'Safe Harbour' is a maritime metaphor, "indicating a place where a ship will be safe from stormy weather". Being outside of safe harbour does not indicate that a ship is in danger but its safety is not assured. ${ }^{12}$ It is a limited protection and not a complete immunity from potential liabilities. The extent of immunity depends on their control over the transmission of the content. As the immunity is only enjoyed by ISP's, the Act covers a broad range of companies that provide services and products that are internet connected. ${ }^{13}$ For this purpose, ISP's are divided into four categories:

(i) transitory digital network communications;

(ii) system caching;

(iii) storage of information on systems or networks at direction of users and;

(iv) information location tools.

These four broad categories of ISPs are involved in the transmission of online content with varying degrees. ${ }^{14}$

The first category is known as mere conduit i.e. the one that provide the transmission to the network communications when the transmission is

${ }^{11}$ Donald P. Harris, "Time to Reboot?: DMCA 2.0", Arizona State Law Journal 47 (2015): 801.

${ }^{12}$ Giancarlo Frosio, "Why keep a dog and bark yourself? From intermediary liability to responsibility", International Journal of Law and IT 26, No. 1, (2017): 1 .

13 "Service provider" is defined in section 512(k)(1)(A) DMCA.

1417 U.S.C. §512 DMCA. 
initiated by a person other than the provider. The whole process normally takes place automatically without selection and without modification. The second category of ISP is the entity that provides system caching. Like the network provider, system caching providers, storage providers and information location tool providers are equally not liable if they do not tamper at all with the contents or are not aware of the infringing activity nor have the ability to curtail or prevent the infringing activity. All these four categories of ISPs are obliged to act expeditiously in taking down or blocking access to the alleged infringing materials.

Therefore, internet intermediaries that merely act as access providers for online content are afforded with limited liability via the safe harbour regime. ${ }^{15}$ It is to be noted that there are two additional conditions as imposed by the DMCA on the service providers. The conditions are;

"(1) that they must adopt and reasonably implement a policy of terminating in appropriate circumstances the accounts of subscribers who are repeating infringers ${ }^{16}$ and (2) it must accommodate and not interfere with 'standard technical measures'."

Another relevant provision is subsection 512(h), in which service providers are also obliged to render necessary assistance towards copyright owners with the aim of identifying and disclosing the identity of suspected infringer to facilitate the implementation of the notice and takedown procedure. ${ }^{17}$

With no active duty to police copyright infringement coupled with the safe harbour system, the internet services attain the relief required for them to prosper. ${ }^{18}$ On the part of the copyright owners, $\S 512(\mathrm{c})(3)(\mathrm{A})$ ) specifically stipulates the conditions to be fulfilled for the purpose of complying with the legal procedure in relation to notice and takedown.

1517 U.S.C. §512(i)(1)(A)-(B) DMCA.

16 Ibid.

17 Standard technical measures in the above provisions refers to applicable technologies used by copyright owners to identify and protect their work such as digital rights management (DRM) and watermarks.

1817 U.S.C. $\$ 512(\mathrm{~m})$ (see also In re Aimster Copyright Litigation, 252 F.Supp.2d 634, 657 (N.D. Ill. 2002), aff'd, 334 F.3d 643, 67 U.S.P.Q.2d (BNA) 1233 (7th Cir. 2003). 
One of the important requirements is that the notice must be properly affixed with either a physical or electronic signature. Another requirement, which is imposed on the copyright owners is pertaining to the identification of both works namely the original copyright work as well as the work infringed. The owner, namely the complainant, must also submit relevant information of himself. The complainant is also obliged to testify that he honestly believes that all the supplied information is precise and accurate for the purpose of proving the unauthorized usage of the copyrighted materials; otherwise he will be liable for perjury.

On this particular relevance, Viacom International, Inc. v. YouTube, Inc., ${ }^{19}$ which is one of the landmark cases brought to the court under the purview of the safe harbour provisions. ${ }^{20}$ The case, which was finally decided in 2013, was also described as a 'test case' to show the application of the safe harbour provision under the DMCA. In this case, Viacom filed a suit against YouTube and Google for copyright infringement. One of the grounds was that the defendants had allegedly facilitated the activities of uploading and viewing of video clips in a large number without the right-holders' authorization. The defendants in their defense sought protection under the safe harbour provisions of DMCA. They also contended that they had complied with thousands of takedown notices, which were submitted to them by the plaintiff. The district court held in favour of the defendants, thus the plaintiff appealed. The appeal court held that defendants/respondents were protected from the liability of the infringement, subject to the exception, namely, where they have the knowledge (includes of willfully ignoring) of any cases of infringement. During the re-examination of these issues by the district court (on remand), judgement was again given in the defendants' (respondents') favour. Apparently, the inference from this decision is that, in the absence of takedown notices, it is not actually necessary for defendants to claim for protection under safe harbour provision of the DCMA $^{21}$. The case is significant in the sense that the safe harbour provision really affords protection to ISPs from liability for copyright

\footnotetext{
${ }^{19}$ No. 07 Civ. 2103, 2010 WL 2532404 (S.D.N.Y 2010).

${ }^{20} 17$ U.S.C. $\$ 512(\mathrm{c})(1)(\mathrm{A})$ DMCA.

${ }^{21}$ Ibid.
} 
infringement unless it can be proved that they have knowledge or awareness of such online infringing activities.

\section{Australia}

In Australia, the relevant safe harbour provisions in relation to copyright affecting service providers were incorporated as part of a bilateral agreement under the Australia - United States Free Trade Agreement (FTA) (Ch 17) in 2004. ${ }^{22}$ Due to this FTA ${ }^{23}$, the Australian copyright safe harbour approach has been largely influenced by the US Title 17 USC 512. In Australia, ISPs are known as 'carriage service providers' (CSP), which is specifically defined under section 87 of the Telecommunications Act 1997. It generally includes parties who use infrastructure, which is provided by a "carrier"e (that is an organisation holding a carrier licence) to supply carriage services to the public. It is to be noted that unless a company is providing internet access in this particular way, it will not be considered as a CSP and hence, would not be entitled to be protected under the Australia's safe harbour provision under the Copyright Act $1968 .{ }^{24}$ Section 86 of the Telecommunications Act 1997 defines "service providers" as: "(a) a carriage service provider; or, (b) a content service provider." Carriage service provider is further defined in section 87 of the same Act to mean:

"(1) For the purposes of this Act, if a person supplies, or proposes to supply, a listed carriage service to the public using: (a) a network unit owned by one or more carriers; or (b) a network unit in relation to which a nominated carrier declaration is in force; the person is a

22 The US FTA Implementation Act 2004 (Cth) Schedule 9 and amended by the Copyright Legislation Amendment Act 2004 (Cth) Schedule 1.

${ }^{23}$ Free trade agreement (FTA) denotes a treaty which is entered between two or more countries that gives benefits to Australia (inclusive importers, exporters, producers and investors). The treaty is aimed to reduce and eliminate certain hindrances to activities involving international trade and investment. The Australia-United States (AUSFTA) was officially entered on 1 January 2005. https://dfat.gov.au/trade/agreements/Pages/trade-agreements.aspx.

${ }^{24}$ A safe harbour scheme for carriage service providers which is set out in Part V, Division 2AA the Australian Copyright Act 1968 which provides limitations on remedies available against carriage service providers. 
carriage service provider".

Section 116AH(1) of the Copyright Act 1968 clearly spells out the required conditions to be complied with by intermediaries if they opt to take advantage of the safe harbour provision, inter alia ; “... a reasonably implemented termination policy for repeat infringers and a notice and takedown regime". Nevertheless, it is to be noted that section $116 \mathrm{AH}$ provides for an exclusion of 'the hosting and indexing' unless the intermediaries receive financial benefit or having the ability to control the activity. Furthermore, Australian CSPs are also exempted from the obligation of keeping under surveillance their service. This means that CSPs are not imposed with an obligation to monitor infringing activities other than what is necessary in assisting copyright holders to identify and protect their works through 'standard technical measures' ${ }^{25}$

Section 116AG of the Copyright Act 1968 limits copyright infringement liability to CSPs through injunctive relief for "transmission, caching, hosting, and indexing activities". This protection is not absolute where CSPs must adhere to the CSP's requirements in section 116A to qualify. Firstly, service providers must satisfy the definition of CSP as provided under section 87 of Telecommunication Act 1997. Secondly, CSP must carry out one of the activities stated in section 116AC $116 \mathrm{AF}$ and satisfy the conditions as laid down therein. In this regard, the Australian law apparently distinguishes between different kinds of Internet intermediaries (CSP) in imposing copyright risk. This leads to a proposal prepared by Australian Law Reform Committee in 2011 which recommended that Australian law should be updated, including to expand the safe harbour provision incorporated in Part V Division 2AA of the Copyright Act 1968. Nevertheless, until today, the Australian

\footnotetext{
${ }^{25}$ As mentioned in condition 2 in table item 1 in the table in subsection (1) of Section 116AH the Australian Copyright Act 1968:-

"If there is a relevant industry code in force- the carriage service provider must comply with the relevant provisions of that code relating to accommodating and not interfering with standard technical measures used to protect and identify copyright material"; Roadshow Films Pty Ltd v iiNet Ltd (2011) 275 ALR 1 - a decision by the Federal Court of Australia which has provided some important guidance to copyright owners pertaining to notices to be given to ISPs as well as the reasonable steps to be adopted by ISPs in upon receiving such notices."
} 
Government has yet to make any amendment to the relevant laws. ${ }^{26}$

It is observed that the US and Australian law differ significantly with regards to information location tools. ${ }^{27}$ Section $116 \mathrm{AF}$ provides that;

"The carriage service provider must expeditiously remove or disable access to a reference residing on its system or network upon receipt of a notice in the prescribed form that the copyright material to which it refers has been found to be infringing by a court."

This also means that the legal obligation of the ISPs to act on the alleged infringing content and materials only arises after the court has determined and pronounced its decision pertaining to their infringing nature. The court is given discretion under section 115A to consider relevant factors such as: "the flagrancy of the infringement, whether the owner or operator of the online location demonstrates a disregard for copyright generally, and whether such an injunction is a proportionate response." 28

\section{New Zealand}

The Copyright (New Technologies and Performers' Rights) Amendment Act 2008 was enacted to introduce a notice-and-takedown regimen and safe harbour provisions, limiting the liability of ISPs. Section 2 defines Internet intermediaries, "to encompass providers of transmission, routing and connection services and hosting service providers." Section 92B, which emulates the Agreed Statement to Article 8 of the WIPO Copyright Treaty 1996, states that:

${ }^{26}$ Kimberlee Weatherall, "Internet Intermediaries and Copyright - A 2018 Update : A policy paper produced for the Australian Digital Alliance”, (2018), accessed October 13, 2018, https://www.aph.gov.au/DocumentStore.ashx?id=79110429-08ee-4b3b-821985071c8c0cee\&subId=563534.

${ }^{27}$ Subdivision B-Relevant activities under Division 2AA - Section 116AF of the Australian Copyright Act 1968 states that: "A carriage service provider carries out a Category D activity by referring users to an online location using information location tools or technology". Relevant provision under US DMCA is 17 U.S. Code $\S 512$.

${ }^{28}$ Section 115A(5)(a)(b)(c) of the Australian Copyright Act 1968. 
"An ISP does not infringe the copyright in a work (for both primary as well as secondary infringement) 'merely because' the ISP's user used those services to infringe the copyright in the work. However, this indemnity does not limit the right holder's ability to seek injunctive relief against the ISP."

Meanwhile, Section 92C which adopts section 512(c) of the United States DMCA, spells out the legal protection and immunity given to an ISP that hosts materials from a third party it has knowledge or reasonable belief of the infringing content. After taking down or blocking access to the infringing content, the ISP is obliged to notify the affected user of its action in blocking the access. Further, Section 92E which emulates section 512(b) of the United States DMCA provides immunity to ISPS that provide cache facilities to users. However, the ISP "does infringe" if it decides to proceed with caching the material despite of its awareness of the deletion of the material from its actual source. Such an infringement would also include the caching of material, which has been ordered by the court to be deleted or not to allow access. On the other hand, liability for copyright infringement does not arise for the service of linking or referrals by an ISP and hence, the safe harbour provision is irrelevant in this scenario. ${ }^{29}$ It is to be noted at this juncture that there is no case-law that supports this argument yet.

In all instances, the indemnity, which is available to the ISP as discussed above does not limit the right holder's avenue to seek for an injunctive relief. Section 92A of the Act which provides that the ISP, "must have policy for terminating accounts of repeat infringers was finally repealed without coming into force", was finally replaced on 1st September 2011 by section 4 of the Copyright (Infringing File Sharing) Amendment Act 2011. The section is mainly aimed to prevent illegal file sharing and to ultimately facilitate a feasible mechanism in assisting

29 Daniel Seng, "Comparative Analysis of the National Approaches to the Liability of Internet Intermediaries", (2010), accessed December 18, 2017, http://www.wipo.int/export/sites/www/copyright/en/doc/liability of internet int ermediaries.pdf; Huthwaite, T., "ISP liability for copyright infringement: Are dodgy subscribers worth the risk?" (2013), accessed September 30, 2018, https://www.baldwins.com/news/isp-liability-for-copyright-infringement-aredodgy-subscribers-worth-the-risk. 
rights-holders to protect and enforce their copyright. ${ }^{30} \mathrm{With}$ regards to procedure, the Act provides for a specific form for copyright owners to be submitted to the ISPs in relation to the infringing material under the service of such an ISP. The relevant provisions are spelt out in sections $122 \mathrm{~A}$ to $122 \mathrm{U}$ of the Copyright (Infringing File Sharing) Amendment Act 2011.

\section{Malaysia}

The Copyright Amendment Act 2012 contains provisions that define the ISP' ${ }^{31}$ subjected to the private notice and takedown procedure. Based on the definition, ISP's are broad enough to include various service providers such as TMNet, P1, Maxis and the like. Such a broad interpretation gives rise to a possibility for the website operators such as Facebook and YouTube to also be included under the meaning of "service provider", as far as the said provision is concerned. Section $43 \mathrm{H}$ confers the right on the owner of a copyright which has been infringed:

"...to notify a service provider to remove or disable access to the electronic copy on the service provider's network. A service provider who has received the notification is required to remove or disable access to the infringing electronic copy on its network within 48 hours from the time of receipt of the notification."

It is submitted that an omission to act as required under the above provision would give rise to liability on the ISP for allowing such an infringing activity which has been brought to its notice. ${ }^{32}$ The owner of

${ }^{30}$ Claire Deeks, "Controversial Copyright (infringing file sharing) Amendment Bill passed into law", (2011), accessed November 30, 2017,http://www.jaws.co.nz/about-us/media/article/controversial-copyrightinfringing-file-sharing-amendment-bill-passed-into; Neha Mishra, "The Role of the Trans-Pacific Partnership Agreement in the Internet Ecosystem: Uneasy Liaison or Synergistic Alliance?", Journal of International Economic Law 20, No.1 (2017): 31.

${ }^{31}$ Section 43B of the Copyright Act 1983.

${ }^{32}$ Section 43E(1)(a)(iii) of the Copyright Act 1983; Ahmad Shamsul Abdul Aziz, Rusniah Ahmad, and Nazura Abdul Manap, "Sekatan Kepada Tanggungan ISP Menurut Akta Hakcipta 1987", Malayan law Journal 5 (2015): cxxii. 
the material which has been removed or to which access has been disabled is also given equal right to respond by issuing a counternotification to the ISP. The counter-notification may contain orders that the ISP restore access or the availability of removed materials. ${ }^{33}$ In this situation, the ISP is obliged to comply with the request within a specific time frame, namely not less than 10 business days, calculated from the day it received the counter-notification. ${ }^{34}$ However, the obligation to restore access would not arise if the issuer of the notification proceeds with a court action. The court order at this stage is important to stop the action of the issuer of the counter-notification, provided that the ISP has been informed accordingly. In the event of losses or damages sustained due to the above process, section $43 \mathrm{H}$ caters for the situation by imposing the duty of compensating the copyright owner.

In essence, compensation would be necessary for any losses or damages due to the ISP's compliance with the notification issued by the copyright owner. Despite the obligation and liability, which may be imposed on the ISP as discussed above, sections 43C to 43E provides for a balanced approach on the matter. These sections expressly provide for an exemption for a list of activities, which include, "transmitting, routing or providing connections of an electronic copy of the work through its primary network". This means that the ISPs would not be liable for copyright infringement for being involved in such activities. Other exemptions, which are also incorporated in these provisions are, system caching and storing via hyperlink or directory, or a search engine. Based on the above legal provisions, it is firmly submitted that Malaysia, by way of implication, follows the private notice takedown procedure, which is in line with the U.S private notice takedown procedure. ${ }^{35}$

\footnotetext{
${ }^{33}$ Section 43H(3) of the Copyright Act 1983.

${ }^{34}$ Section 43H(4)(a)\&(b) of the Copyright Act 1983.

${ }^{35}$ Mira Burri, "The Governance of Data and Data Flows in Trade Agreements: The Pitfalls of Legal Adaptation", U.C. Davis L. Rev. 51 (2017): 65 - The author argues that Malaysia would need to adopt "notice and takedown' mechanism as part of its obligation under the TPP.
} 


\section{NOTICE AND NOTICE TAKEDOWN PROCEDURE}

The discussion now continues with an explanation on the second type of safe harbour method which has been adopted by Japan and Canada.

\section{Japan}

Japan has a specific legislation governing the intermediary liability, namely the Act on the Limitation of Liability for Damages of Specified Telecommunications Service Providers and the Right to Demand Disclosure of Identification Information of the Senders, which was enacted in 2001. The Act aims to embrace all kinds of infringements, including and without limitation to, copyright and trademark infringement, defamation, and breach of privacy. It essentially applies to a "specified telecommunications service provider" and this includes a bulletin board/website administrator, hosting service provider, and access provider, but excludes email, chat, messenger and other types of providers. Article 3 regulates the limitation of ISP's liability for damages (not safe harbour). An ISP does not owe liability unless it fulfills the following requirements:

(i) has knowledge of the infringement, or

(ii) has knowledge of the information distribution and there is a reasonable ground to find that it could know the infringement. ${ }^{36}$

The law is clearly designed to set out specific limitations to the liability of ISPs, as well as other related parties which include administrators and system operators of bulletin boards, those who provide hosting services, and others in relation to copyright infringement. It does not impose any obligation on an ISP to remove offensive or infringing materials unless it can be proved that they have the capability in respect of the technology to do so, and provided they are aware of the infringing material or it can be inferred that they have obtained the knowledge about it. This means that the element of knowledge is a prerequisite if ISPs were to be held liable for failure to take down infringing

\footnotetext{
${ }^{36}$ Article 3 Limitation of Liability for Damages of Specified Telecommunications Service Providers and the Right to Demand Disclosure of Identification Information of the Senders.
} 
materials online. It also provides for specific situations whereby ISPs may provide some personal information of an internet user to the person asking for such information. The Provider Liability Limitation Law 2002 is significant, as it limits ISPs' liability for copyright infringing content. ${ }^{37}$

In order to enjoy safe harbour, an ISP is obliged to provide a notice to the alleged infringer namely the subscriber after the takedown notice is given. A period of seven days is allocated for an explanation from the subscriber to justify the content. In the event that the subscriber fails or omits to provide necessary explanations, the ISP may then proceed to take down the material. ${ }^{38}$ Since the type of notice by the copyright owner is not specified, there is a need for some guidelines in assisting the ISPs to takedown the materials. In response to this, major associations of ISPs have been working together with copyright owners to produce a 'voluntary guideline'. The guideline is significant in the sense that it clarifies the type of notice required on the part of the copyright holder. It also includes a credibility certification organization to facilitate immediate action by the ISP in taking down the online infringing materials. This model is known as the 'notice and notice' model which is supported by industry guidelines ${ }^{39}$ working to ensure a much more efficient mechanism. ${ }^{40}$ In this way, ISPs have choices of making suitable

${ }^{37}$ Article (1) \& 3(1) Act No. 137 of 2001.

${ }^{38}$ J.Dax Hansen and Keiji Sugiyama, "A Web of Rules: How the Internet is affecting Japanese content liability, privacy and consumer protection laws", (2002), accessed $\quad 30 \quad$ September 30, 2018, http://www.japaninc.com/article.php?articleID=945 .

${ }^{39}$ For example, Guideline regarding Defamation and Breach of Privacy, Guideline regarding Copyright Infringement, Guideline regarding Trademark Infringement \& Guideline regarding Sender's Identification Information Disclosure Request; Naoko Mizukoshi, "Case Study: Intermediary Liability Rules in Japan", (2015), accessed September 30, 2018, https://opennet.or.kr/wpcontent/uploads/2015/06/Session-1-2Naoko-MizukoshiCase-StudyIntermediary-Liability-Rules-in-Japan.pdf.

${ }^{40} \mathrm{Ibid}$. Efficient in the sense of much clearer procedures and related matters. The Guidelines as mentioned in the above note describe in clarity with regards to the notice such as the procedure to notify ISPs, the format to be used for notice. It also includes recent ISP's standard practices based on judicial precedents. Besides, where the issue is not spelt out in the Act, ISPs may delete 
responses and actions to cater to infringement issues, according to different circumstances. ${ }^{41}$

\section{Canada}

The governing legislation in relation to ISP liability in Canada is the Copyright Modernization Act 2012 (CMA), which came into effect at the beginning of 2015. ${ }^{42}$ The CMA reflects a comprehensive reform of Canadian copyright law and one of the primary objectives is to tackle some challenging issues involving online intermediaries, in particular their liabilities for cases of copyright infringement. ${ }^{43}$ The CMA adopts a "notice and notice" procedure ${ }^{44}$ which came into force in January 2015 and this is obviously different compared to the "notice and takedown" procedure practiced by the United States.

It is interesting to note that CMA targets online services that are

illegal information (e.g. obscenity, illegal drugs) subject to another guideline, according to the relevancy.

41 Vikrant Narayan Vasudeva, "The Notice and Takedown Procedure under Copyright Law: Developing A Measured Approach", (2011), accessed November 15 ,

2017 , http://www.austlii.edu.au/au/journals/UNDAULawRw/2011/7.pdf; BSA, "Country Report: Japan", (2012), accessed September 30, 2018, https://cloudscorecard.bsa.org/2012/assets/pdfs/country_reports/Country_Repor t_Japan.pdf; Nicolo Zingales, "Internet intermediary liability: Identifying best practices for Africa", (2013), accessed September 30, 2018, https://www.apc.org/sites/default/files/APCInternetIntermediaryLiability_BestPr acticesAfrica 20131125.pdf p.33; Yijun Tian, Re-thinking Intellectual Property: The Political Economy of Copyright Protection In The Digital Era, (Routledge-Cavendish, 2009), 193.

42 Copyright Act, Justice Laws Website, accessed 17 December 2018, https://laws-lois.justice.gc.ca/eng/acts/c-42/.

43 F. Joli-Coeur, "Canada's Approach to Intermediary Liability for Copyright Infringement: The Notice and Notice Procedure", (2014), accessed October 14, 2017, http://btlj.org/2014/03/canadas-approach-to-intermediary-liability-forcopyright-infringement-the-notice-and-notice-procedure/.

${ }^{44} \S \S 41.25$ and 41.26 CMA. 
designed primarily to enable copyright infringement. ${ }^{45}$ The Notice and Notice procedure commences with an action by copyright owner i.e. to notify an ISP on the infringement, which has occurred. Sections 41.25 clearly stipulates:

"the notice must identify the work to which the claimed infringement relates, specify the electronic location to which it relates, and specify the infringement that is claimed".

Once the ISP receives the notice, there is no obligation imposed on it to remove the alleged infringing material. Nevertheless, the ISP is required to forward the notice to the alleged infringer ${ }^{46}$ and must retain records for 6 months to enable the disclosure of the information and identity of the alleged infringer. In the event that the right owner decides to proceed with court proceedings, the record must be retained for one year, calculated from the date of the reception of the notice. ${ }^{47} \S 41.26(3)$ further provides that if an ISP fails to comply with any of its duties under the Notice and Notice procedure, the right owner is entitled to statutory damages between 5000 CAD and 10000 CAD. Since the CMA includes a provision ${ }^{48}$ requiring notices to be forwarded to subscribers, it means that ISPs are obliged to notify their subscribers after they have received relevant notification on the alleged infringing copyright materials. Despite the criticisms by the copyright owners on the Notice and Notice system as being less effective because it is too lenient, ${ }^{49}$ most Canadian ISPs generally give favourable feedbacks and strong support towards the system. ${ }^{50}$

\footnotetext{
${ }^{45} \S \S 18(2.3)$ CMA.

${ }^{46} \S 41.26(1)(a)$ CMA.

${ }^{47} \S 41.26(1)(b)$ CMA.

$48 \S 41.26(1)(\mathrm{a})$ CMA.
}

49 BSA, "Business Software Alliance Country Report: Canada", (2016), accessed December 15, 2017,

http://cloudscorecard.bsa.org/2016/pdf/country_reports/2016_Country_Report_ Canada.pdf.

${ }^{50}$ Anna Spies, "Balancing the rights of copyright holders, internet users and ISPs in an internet age: Recent developments in ISP liability in Australia, 


\section{COURT ORDERED TAKEDOWN NOTICES}

As noted previously, the court ordered takedown notices is another method that has been adopted by certain countries when dealing with the liabilities of ISPs in the face of infringing content.

\section{Chile}

The liability of ISPs is mainly governed by the Intellectual Property Law (i.e. Law No. 20,430 which amends Law No. 17,336). ${ }^{51}$ The amendment to the law took place in May 2010 and it includes provisions to regulate ISP liability. The amendment is significant in the sense that it gives exemption to the ISPs from liability in removing infringing content once they become aware of its existence. The element of knowledge of such infringing content is inferred on the basis that the ISPs have received legal notice. This means that under the new copyright law, the liability to take down content arises once a court order has been issued..$^{52}$ This requirement has not gained support from most copyright owners as they are of the view that a court action would take a longer time as compared to a private notification. The reaction and responses stem from the fact that these copyright holders need an effective mechanism, which caters to a speedy removal of the infringing content, as most of the time, online materials would require a large-scale removal action. ${ }^{53}$ It seems Chile's

Canada and New Zealand", MALR 16(2011):341; Matthew Rimmer, "Back to the Future: The Digital Millennium Copyright Act and the Trans-Pacific Partnership", (2017), accessed September 30, 2018, www.mdpi.com/2075$\underline{471 X / 6 / 3 / 11 / p d f}$.

51 English translation is available at
https://www.cdt.org/files/file/ChileanLaw20430-ModifyingLaw17336.pdf .

${ }^{52}$ Susy Frankel, S. \& Daniel Gervais, The Evolution and Equilibrium of Copyright in the Digital Age, (Cambridge University Press: 2014), 98-99; Rebecca Giblin, Evaluating Graduated Response, Columbia Journal of Law \& the Arts 37 (2014): 147.

53 Jyoti Panday, et al., "Jurisdictional Analysis: Comparative Study Of Intermediary Liability Regimes Chile, Canada, India, South Korea, UK and USA in support of the Manila Principles On Intermediary Liability", (2015), accessed October 2 , 2018 , https://www.eff.org/files/2015/07/08/manila_principles_jurisdictional_analysis. 
approach to this issue is rather conservative if viewed from the perspective of the copyright owners.

\section{Singapore}

ISPs in Singapore are generally protected from both civil and criminal liabilities under a specific legislation, namely the Electronic Transactions Act $1998 .{ }^{54}$ As far as the liability of the ISP is concerned, Section 10 of the Act generally aims for cases relating to IP infringement, as well as defamation. ${ }^{55}$ In 2014, Singapore updated its copyright laws to introduce some new provisions pertaining to "flagrant" online copyright infringement. ${ }^{56}$ These new provisions which are described as a unique approach, are significant in the sense that they are designed to replace the former legal mechanism involving the takedown notice, which was found to be ineffective to counter high volume of online copyright infringing content in Singapore. ${ }^{57}$ Under the new system, a copyright holder is required to apply and successfully obtain a High Court injunction as evidence to prove that an online location has "flagrantly" infringed a

pdf, pp.29 , 46-47, 51; Rodrigo Lavados Mackenzie, "Chile Breaks New Ground in Regulating IP Liability", (2010), accessed September 5, 2017, http://www.wipo.int/wipo_magazine/en/2010/03/article_0009.html; Andrew McDiarmid, "Chile's Notice-and-Takedown System for Copyright Protection: An Alternative Approach", (2012), accessed December 21, 2017, https://cdt.org/files/pdfs/Chile-notice-takedown.pdf; Neha Mishra, "The Role of the Trans-Pacific Partnership Agreement in the Internet Ecosystem: Uneasy Liaison or Synergistic Alliance?", Journal of International Economic Law 20, No. 1 (2017): 31.

${ }^{54}$ Section 10 of the Electronic Transactions Act 1998.

55 Dan McDonald, “ ISP Liability in Singapore: Lessons For Canada?”, Murdoch University Electronic Journal of Law (2002), accessed December 26, 2017, http://www.austlii.edu.au/au/journals/MurUEJL/2002/5.html.

${ }^{56}$ Section 193DDA \& Section 252CDA of the Copyright Act 2006 (as amended 2014).

${ }^{57}$ Lau Kok Keng \& Darren King, "Amendments to the Copyright Act 2014: A Block-buster In The Making?", (2014), accessed September 30, 2018, https://www.rajahtannasia.com/media/1291/amendments-to-the-copyright-act2014-a-block-buster-in-the-making.pdf . 
copyright. The copyright owners who managed to obtain the injunction from the court are then entitled to request via a short notice to the ISP to take down the infringing site. The relevant provisions are contained in Part IX A of the Copyright Act 2006, as amended by the Copyright Amendment Act 2014 (Act 22 of 2014). ${ }^{58}$ The Copyright (Flagrantly Infringing Online Location) Regulations 2014 (S 802 of 2014) (99 $^{59}$ were issued in December 2014, requiring mandatory takedown after a period of 14 days if reasonable attempts have been made to issue a notice to the provider of the material. The amendment has essentially enabled copyright owners to apply directly to the courts to obtain the orders instead of having to establish liability of the ISP (Section 193DDA of the Act). ${ }^{60}$

Section 193D of the Copyright Act further stipulates that, "ISPs will be held liable only if they receive a financial benefit from the infringing content and they fail to meet a series of 'safe harbour' tests". Before the 2014 amendments, the position was that, failure to give a positive response to any take-down notices will expose the ISPs to a suit of copyright infringement by the right holders. The court action by the right holder is mainly for the purpose of seeking for an injunction to compel the ISP to remove the infringing content or disabling access to it, wherever appropriate. Nevertheless, this avenue is not so popular among right holders due to some inherent reasons, inter alia the burdensome costs of court litigation as well as the uncertainty in proving ISP's liability during the trial.

This problem was addressed in the 2014 amendments whereby now there is no need for the right holders to file a legal suit and go through and long process of court trial, instead they can now choose to submit a

${ }^{58}$ Republic of Singapore Government Gazzette, "Copyright (Amendment) Act 2014”, accessed 23 December 2018, https://sso.agc.gov.sg/Acts-Supp/222014/Published/20141202?DocDate $=20141202$.

59 Ibid.

${ }^{60}$ Ministry of Law, Singapore, "Amendments to the Copyright Act”, (2014), accessed December 13, 2017,

http://www.mlaw.gov.sg/content/minlaw/en/news/press-releases/amendmentsto-thecopyright-act-2014.html 
direct application to the courts seeking for injunctions to order the ISP to remove infringing content or block access to the relevant sites. ${ }^{61}$ It is submitted that the approach taken by Singapore is more favourable to the IP holders if compared to the position in Chile.

\section{NO EFFECTIVE TAKEDOWN PROCEDURE}

This part of the article gives a brief overview of the position in Peru, Brunei, Mexico and Vietnam where there is no effective takedown procedures adopted when dealing with the responsibilities of ISPs to takedown infringing content.

\section{Peru}

As far as ISP liability is concerned, the relevant legislation, which regulates copyright infringement matters in Peru is the Copyright Law (Legislative Decree No. 822 of April 23, 1996) and the Law Amending, Incorporating and Regulating Miscellaneous Provisions on the Implementation of the Trade Promotion Agreement Signed between Peru and United States. It is to be noted that prior to 2006 these laws did not have any specific section on ISP's liability. The provisions relating to

${ }^{61}$ Lau Kok Keng, "Amendments to the Copyright Act 2014: A Block-buster In The Making?", (2014), accessed November 27, 2017, http://www.rajahtannasia.com/media/1291/amendments-to-the-copyright-act2014-a-block-buster-in-the-making.pdf; Gabriel Lim Zhi-Hao, "Online Privacy: Issues Faced by Content Holders in Enforcing their Intellectual Property Rights", Juris 8 (2017), accessed September 30, 2018, http://www.singaporelawreview.com/juris-illuminae-entries/2017/onlineprivacy-issues-faced-by-content-holders-in-enforcing-their-intellectual-propertyrights; Eileen Yu, "Singapore Android TV sellers face copyright infringement charges", (2018), accessed September 30, 2018, https://www.zdnet.com/article/singapore-android-tv-sellers-face-copyrightinfringement-charges/ - It was reported that four companies have filed a copyright infringement lawsuit against two Android TV box sellers in Singapore, on the basis of the Copyright Act's Section 136 (3A); Chia-Ling Koh, "Copyright: site-blocking in Singapore", (2017), accessed September 30, 2018, http://www.osborneclarke.com/insights/copyright-site-blocking-insingapore/. 
notice and takedown obligation on ISPs were first introduced in Peru after the bilateral agreement with the US in $2006 .{ }^{62}$

The US-Peru FTA has led to the reform of the Peruvian copyright laws in $2009 .{ }^{63}$ Despite the reform, the amendment did not actually incorporate specific provisions on notice and takedown requirement. In late 2012, the effort was revived when the Peruvian Government announced its intention to regulate the intermediary liability provisions from the US-Peru FTA by incorporating them into its national law. However, this process was later stopped without clear outcomes or proposals as most stakeholders and public at large were against such a regulation. ${ }^{64}$

\section{Brunei}

ISPs in Brunei enjoy almost total exemption from both civil and criminal liabilities for providing services which may contain infringing content. The governing legislation is the Electronic Transactions Order, 2000. Besides the exemption, there is neither specific procedure nor legal incentive if an ISP decides to proceed with removal of infringing

62 Via a side letter to the US-Peru FTA date 12 April 2006, https://ustr.gov/sites/default/files/uploads/agreements/fta/peru/asset_upload_file 437_9548.pdf.

${ }^{63}$ Law Amending, Incorporating and Regulating Miscellaneous Provisions on the Implementation of the Trade Promotion Agreement signed between Peru and United states (Law No. 29316 of January 13, 2009).

${ }^{64}$ Miguel Morachimo, "Lessons from Peru: A tough start to regulating ISP liability", (2013), accessed September 30, 2018, http://infojustice.org/archives/28175 ; Pasquale De Micco, The US and EU free trade agreements with Peru and Colombia: A comparison, (2014):10-11, accessed September 30, 2018, http://www.europarl.europa.eu/RegData/etudes/briefing_note/join/2014/522326/ EXPOINTA_SP\%282014\%29522326_EN.pdf; Sean M. Flynn, et al, The U.S. Proposal for an Intellectual Property Chapter in the Trans-Pacific Partnership Agreement, American University International Law Review 28 (2012): 105. 
materials after it has received notice from right holders. ${ }^{65}$

Section 10 of the Order for instance, clearly spells out that there would be no liability on ISP for hosting infringing third party content. In such a situation, the right holders are left with the option of either handling the situation via contractual agreement with the ultimate purpose of taking down infringing content, or by applying a specific written law, which includes application for a court's order to remove, take down, block or deny access to any infringing materials online. In short, the digital rights of the right holders are not protected under the Order due to the non-existence of adequate incentives for ISPs to take relevant action in respect of the infringement. ${ }^{66}$

\section{Mexico}

The issues relating to ISPs' liability in Mexico are only addressed via general liability principles in the copyright legislation, and hence it is not surprising that there have been no cases filed in relation to the matter. ${ }^{67}$ The Copyright Law of Mexico (i.e. Federal Law on Copyright, ${ }^{68}$ December 24, 1996, as amended on July 14, 2014) does not incorporate any provisions on safe harbour for the purpose of exemption of the ISPs'

65 Matthew Rimmer, "The Trans-Pacific Partnership: Copyright Law, The Creative Industries, And Internet Freedom", (2016), accessed October 1, 2018, https://eprints.qut.edu.au/101783/1/Dr\%20Matthew\%20Rimmer\%20TPP\%20an d\%20Copyright\%20October\%202016.pdf.

66 Ismichels, "Enforcing Online Copyright Protections Abroad: Part II - South and East Asia", (2014), accessed November 30, 2017, https://theipexporter.com/category/brunei-darussalam; GIPC, "Unlimited Potential-The Global Innovation Policy Center: Intellectual Property in the Trans-Pacific Partnership (TPP)", (2015), accessed October 1, 2018, http://www.theglobalipcenter.com/wp-content/uploads/2015/07/GIPC-IndexTPP.pdf.

${ }^{67}$ Luis Schmidt, “The ISP's Responsibilities in Protecting Copyright”, (2013), accessed October 17, 2017, http://www.managingip.com/Article/3270552/TheISPs-responsibilities-in-protecting-copyright.html.

68 Mexico, WIPO, accessed 17 December 2018, http://www.wipo.int/wipolex/en/text.jsp?file_id=340767. 
liability in providing their online services such as routing, caching and the like. Although the copyright law provides for some limitations and exceptions, the scope and application are very narrow and would be very hard for right owners to prove the issues of online copyright infringement. ${ }^{69}$

Another relevant legislation is the Telecommunications Law, which contains some provisions that mandates the ISPs to hold customers' personal information against the request of right holders. Such a nondisclosure by the ISP is allowed by the law, even in situations where the right holders decide to proceed with civil recourse and hence the information is vital to facilitate the action. As far as liability for infringement is concerned, the ISPs are exempted from liability for providing internet connection and services to the copyright infringers. ${ }^{70}$

\section{Vietnam}

ISP liability in Vietnam is governed by the Joint Circular No.07/2012/TTLT-BTTTT-BVHTTDL on Stipulations on the Responsibilities for Intermediary Service Providers in the Protection of Copyright and Related Rights on the Internet and Telecommunications Networks. ${ }^{71}$ This legislation has been used to manage ISP liability in general due to the non-existence of specific laws in relation to ISPs'

${ }^{69}$ Luis Schmidt, "Notice and take down before NAFTA", (2018), accessed October 1, 2018, http://www.olivares.mx/wp-content/uploads/2018/02/olivaresfinal-jan-18.pdf; Pablo Wegbrait, "Internet service provider liability for copyright infringement in Latin America", (2014), DOI: 10.1017/CBO9781107477179.013.

${ }^{70}$ Jose Camarena, "WILMap: Mexica", (2015), accessed November 20, 2017, http://cyberlaw.stanford.edu/page/wilmap-mexico; Rimmer, M., "The TransPacific Partnership,"; The Global IP Center, "Unlimited Potential-The Global Innovation Policy Center: Intellectual Property in the Trans-Pacific Partnership (TPP)", (2015), accessed October 1, 2018, http://www.theglobalipcenter.com/wp-content/uploads/2015/07/GIPC-IndexTPP.pdf.

71 Copyrights Office of Vietnam, accessed 17 December 2018, http://www.cov.gov.vn/cbqen/index.php. 
liability for infringing materials on the internet. ${ }^{72}$ In cases involving right holders' infringement, they have the right to refer the matter to some competent parties which include the Inspectorates of Ministry of Culture, Sports \& Tourism and the Ministry of Information \& Communication. They may also proceed to file a case in court and proceed with trial. The above ministries would generally provide a proper advice or relevant order wherever necessary within a specific time frame imposed on them.

The absence of an appropriate provision on the ISPs' liability with respect to copyright infringement is apparently the primary reason which prevents the right holders from protecting their digital rights. ${ }^{73}$

\section{STRENGTHS \& WEAKNESSES OF EACH SYSTEM}

The U.S. style of notice and takedown procedure under the safe harbour system has been criticized for many reasons, such as the high possibility that the takedown notices would be misused ${ }^{74}$ and absence or lack of due process and private censorship. ${ }^{75}$ The criticism and concerns are not without merits as there exists some data from various literatures ${ }^{76}$ which

72 BSA, "Business Software Alliance Country Report: Vietnam", (2016), accessed December 15, 2017, http://cloudscorecard.bsa.org/2016/pdf/country reports/2016_Country_Report Vietnam.pdf.

${ }^{73}$ AmCham. "Intellectual Property Rights in the Socialist Republic of Vietnam", (2013), accessed February 28, 2017, http://www.amchamhanoi.com/wpcontent/uploads/2014/01/special301old.pdf; Matthew Rimmer, "The TransPacific Partnership"; GIPC, "Unlimited Potential."

${ }^{74}$ Shira Perlmutter, "Making Copyright Work for a Global Market: Policy Revision on Both Sides of the Atlantic", Colum. J.L. \& Arts 38 (2014):49.

${ }^{75}$ Gwen Hinze, "Internet Service Providers' Liability: Copyright enforcement and Free Speech Issues", (2005), accessed October 4, 2018, https://pdfs.semanticscholar.org/presentation/6925/660a5ca3f4cc777ed6ca4a76 2d0c11ad7228.pdf .

${ }^{76}$ Althaf Marsoof, 'Notice and takedown': A copyright perspective, Queen Mary Journal of Intellectual Property 5, No. 2 (2015):183-205; Mohammad Sadeghi, The Knowledge Standard for ISP Copyright and Trademark Secondary Liability: A Comparative Study on the Analysis of US and EU Laws, (PhD diss., 
shows that there is a high incidence of questionable uses of the process in the application of the private notice takedown system. It has also been reiterated that the issue of copyright infringement needs a careful and close scrutiny as even a careful sender may submit a notice to the ISP with claims that require court's review and intervention before the alleged infringing material is taken down or removed by the ISP. In this regards, U.S style of safe harbour apparently creates incentives for ISP to proceed with taking down materials even based on unproven allegation of infringement.

From another perspective, the safe harbour provision is seen as a factor leading towards anti-competitive misuse and in some instances, the provisions are also being said to be too narrow to afford complete protection to the ISPs ${ }^{77}$ as they do no cover all categories of ISPs or all online activities, such as 'Google caching'. In relation to the issue of privacy, the privacy of content owners are not strongly protected due to the fact that a simple subpoena to an ISP will ultimately give away the identity of a content owner. ${ }^{78}$ Besides that, the private notice takedown system also requires ISPs to practice self-regulation on the internet by way of active monitoring of the infringing contents. This obligation has its implication, in the sense that the ISP is placed in difficult situation of determining which content to be blocked or removed. Not only that, the system has also been criticized for leaving behind the interest of average users of the internet, despite the fact that the group is the most affected

Brunel University London, 2013); Vasudeva, "The Notice And Takedown Procedure"; Jennifer M. Urban, Joe Karaganis, \& Brianna Schofield, Notice And Takedown In Everyday Practice, (BerkeleyLaw University of California:2017); Judit Bayer, "Liability Of Internet Service Providers For Third Party Content", (2007), accessed October 12,2018, https://www.victoria.ac.nz/law/research/our-research/past-researchprojects/internetnz-working-papers/Bayer.pdf .

${ }^{77}$ Nathan Lovejoy, "Standards For Determining When ISPs Have Fallen Out Of Section 512(a)", Harv. J. Law \& Tec 27 (2013): 257.

${ }^{78}$ Habib Sani Usman, Implicate the middleman? The Strength and weakness of the "Good Samaritan Doctrine" in providing a legal shield for Internet Service Providers (ISPs) against the liability of third party contents., (Master diss., Tilburg University Law School, 2014). 
ones under the DMCA provisions ${ }^{79}$.

With regards to the "notice and notice" takedown procedure as being practiced in Japan and Canada, which is also known as the horizontal approach, it has been described ${ }^{80}$ as being favorable compared to all other systems. This is premised on the fact that the ISPs are not imposed with the obligation to monitor the content of the materials which are made available on the internet by the ISPs' customers or subscribers. Some authors pointed out the strength of this kind of system as being favorable to ISPs on the basis that the system leaves them to act as "a mere gobetween and places any legal decision making and interpretation of copyright legislation rightly in the hands of the courts". ${ }^{81}$ The ultimate decision to remove and takedown the alleged infringing material could only be carried out with a judicial order. In this way, due regards of the various parties' interests are the paramount consideration. In addition, the dispute is confined to only two specific parties, namely the right-owner and the alleged infringer, and they would be solely responsible for the cost of judicial proceedings.

Admittedly, this system apparently takes a less aggressive approach in the sense that the complaint is forwarded to the alleged offender and hence, it does not have the effect of inhibiting freedom of expression since ISPs are not immediately obliged to block access to an entire website simply based on any allegation of copyright infringement. ${ }^{82}$ Despite the fact that 'notice-notice system' has proven to be useful in creating awareness among internet users on the limitation of copyright, the system is also been used as a powerful weapon by the copyright owners to commence lawsuits against the alleged infringers. In Canada for instance, thousands of lawsuits have been filed by the right holders under this system in order to obtain their required information of

${ }^{79}$ Emily M. Asp, Section 512 of the Digital Millennium Copyright Act: User Experience and User Frustration, Iowa L. Rev. 103 (2018): 751.

${ }^{80}$ Vasudeva, "The Notice and Takedown Procedure".

81 Jason Rudkin-Binks, and Melbourne, S., 'The New “Three Strikes” Regime For Copyright Enforcement In New Zealand - Requiring ISPs to Step Up to The Fight', Entertainment Law Review 20, No. 4 (2009):146, 149.

${ }^{82}$ Ibid. 
subscribers from ISPs without incurring further cost. ${ }^{83}$

For the third system, which is practised in Chile and Singapore, ${ }^{84}$ the court's role serves as a paramount importance as they rely solely on the court ordered notices system. Despite the inherent argument that courts are generally slow to provide a prompt response in encountering a massive number of copyright infringements, the strength of such system lies on the fact that the affected parties are be able to prove the legality of the content before a court of law. It provides a clear assurance that the removal of the content could be carried out by the ISP once the legality of the content is established vis-a-vis a legitimate notice by the right holder. In Chile for instance, there are two conditions which must be fulfilled. Firstly, there must be a judicial order by a competent court requiring that the content be removed or that access be disabled; ${ }^{85}$ and secondly, upon notice of such judicial order, the service provider must have failed to comply with it "expeditiously". ${ }^{86}$

${ }^{83}$ Michael Geist, "Notice the Difference?: Supreme Court Rules ISPs Can Be Compensated for Copyright Costs", (2018), accessed October 12, 2018, http://www.michaelgeist.ca/2018/09/notice-the-difference-supreme-court-rulesisps-can-be-compensated-for-copyright-costs/; The ISP's obligation under the notice and notice regime in Canada was discussed in Rogers Communications Inc. v. Voltage Pictures, LLC (2018) SCC 38; Erin Creber, "Online Copyright Enforcement Gone Wrong - How To Get it Right", (2016), accessed October 12, 2018, http://www.smart-biggar.ca/en/articles_print.cfm?news_id=1195.

${ }^{84}$ See PCCW Media Ltd v M1 Ltd [2018] SGHC 99 - The case was decided based on Section 193DDA Singapore Copyright Act (Cap 63, 2006 Rev Ed) in relation the Court's power to order to disable access to flagrantly infringing online location.

${ }^{85}$ See (Chile) Law No. 17336, article 85 Ñ, second subsection: "The service provider shall be understood to have actual knowledge when a competent court, pursuant to the procedure set forth in article $85 \mathrm{Q}$, has ordered that the data should be removed or that access should be disabled, and the service provider has been legally notified of such order and nevertheless fails to comply with it expeditiously."

${ }^{86}$ Claudio Ruiz Gallardo \& J. Carlos Lara Gálvez, Liability of Internet Service Providers (ISPs) and the exercise of freedom of expression in Latin America, accessed October 12, 2018, https://www.palermo.edu/cele/pdf/english/InternetFree-of-Censorship/02- 
Other than Chile, Singapore is another example to represent a system with the court's intervention. The system is working well ${ }^{87}$ as there exists a strong mutual commitment by the relevant industry and the government in working cooperatively to protect the rights and interests of copyright holders from illegal infringement.

\section{CONCLUSION}

Does one size fit all? TPP imposes the US private notice system on the rest of the members. Being the pioneer in regulating the liability of ISP's, the US system has often been portrayed as a better option and hence to be adopted as the global standard to be applicable to other jurisdictions. ${ }^{88}$ Alas, as shown above the safe harbour system is not the only system in practice.

This paper examines two other alternatives; the notice-notice system and the court ordered takedown system. All the systems have their own strengths and weaknesses, but undoubtedly, it can be said that the other two alternatives also provide justice to the alleged ISPs and thus afford

Liability_Internet_Service_Providers_exercise_freedom_expression_Latin_Am erica_Ruiz_Gallardo_Lara_Galvez.pdf.

${ }^{87}$ For example, on $11^{\text {th }}$ February 2016, Singapore High Court issued a blocking order against SolarMovie as the case fits the statutory criteria of a Flagrantly Infringing Online Location, See Clara Cheo \& Mark Shaw, "Score one for the good guys: protecting Singapore's creativity", (2016), accessed October 12, 2016, http://www.contentpromotion.net/dynamic-content/c-score-one-for-thegood-guys-protecting-singapore-s-creativity.

${ }^{88}$ There are many write-ups which suggest and support this presumption, such as: Anupam Chander, "Internet Intermediaries as Platforms for Expression and Innovation", (2016), accessed October 1, 2018, https://www.cigionline.org/sites/default/files/documents/GCIG\%20no.42.pdf; Ali Amirmahani, Digital Apples and Oranges: A Comparative Analysis of Intermediary Copyright Liability in the United States and European Union, Berkeley Technology Law Journal 4(2015):12; Vishnumohan Rethinam, Endless flotillas and safe harbours: perspectives on ISP and host liability, (2016), accessed October 1, 2018, https://www.worldtrademarkreview.com/enforcement-and-litigation/endlessflotillas-and-safe-harbours-perspectives-isp-and-host. 
reasonable protection to them. From the perspective of the web site owners, justice is apparently done via the notice-notice system as it enables them to explain their positions, while the court ordered takedown in essence reduces the arbitrariness that might arise from the private notice system. This is because the latter allows action to be taken only after being judicially determined by the court. All in all, the other two systems represent versions of DMCA private notice and takedown but attached with feature of checks and balances via court orders or the right to rebut claims before the alleged infringing material is taken down by the ISP. ${ }^{89}$

The article had argued that since the US notice and takedown procedure is also not without its flaws, it should not be regarded as the only feasible system in dealing with copyright infringement. Different countries apparently have different social and economic needs and circumstances, which requires different systems to be in place. As discussed above, since the existing systems in some of the TPP member countries are already working towards achieving the common objective in dealing with copyright infringement, there are no compelling reasons why they should be replaced with one particular system. On that score, it has to be reiterated that although copyright enforcement on digital rights has a strong basis and is therefore vital, such enforcement may eventually give a long-term effect to the open nature of the internet. Clearly, this is a situation where one size does not fit all.

\section{ACKNOWLEDGMENT}

This work and related research is funded by the Ministry of Education, Malaysia via Fundamental Research Grant Scheme (FRGS) No. 15-1830424.

${ }^{89}$ Cory Doctorow, What's Wrong with the Copyright Office's DRM Study? Boing Boing, (2017), accessed October 13, 2018,

http://boingboing.net/2017/06/29/absolutely-nothing-say-it-agai.html. 